\title{
THE CONCEPT OF BUSINESS CLUSTERS AND ITS IMPACT ON TOURISM BUSINESS IMPROVEMENT
}

Vuk Mirčetić, Svetlana Vukotić2 ${ }^{2}$ Drago Cvijanović ${ }^{3}$

*Corresponding authorE-mail: info@vukmircetic.rs

\begin{tabular}{l} 
A R T I C L E I N F O \\
Review Article \\
Received: 29 August 2019 \\
Accepted: 14 September 2019 \\
doi:10.5937/ekoPolj1903851M \\
UDC 338.486.41 \\
\hline
\end{tabular}

Keywords:

Tourism, Clusterism, Business Development, Serbian Tourism Cluster Model.

JEL: Z32, R58

\section{A B S T R A C T}

Increasing competition in the tourism market leads to the justified need for forming tourism clusters. Joining in clusters has numerous benefits for cluster members. Clustering leads to increased competitiveness of cluster members, because of the improved productivity and efficiency of work, adopted innovations, development of new technologies and introduction of the new quality standards and better market access. The purpose of this paper was to analyze tourism clusters models and to introduce the most suitable tourism cluster model for Serbia, based on the examples of good practice. Authors conducted a comprehensive literature review and proposed a new definition for cluster and accordingly determined new tourism cluster definition. Context of research is mostly related to cluster members. This paper contributes to research and development of clusters with a particular review of tourism clusters and suggests decision-makers in tourism what is the most suitable tourism cluster model they should consider.

(C) 2019 EA. All rights reserved.

\section{Introduction}

Globalization affects all aspects of modern living, so business representatives need to adapt. Competition in the tourism market is rapidly increasing. There are many stakeholders in this business conditions, such as areas of different size (countries, regions, cities and micro areas), small and medium-sized enterprises, large businesses and individuals. Because of the variety of tourist destination, tourists are also becoming

1 Vuk Mirčetić, Teaching Associate, Faculty of Applied Management, Economics and Finance, Jevrejska 24, Belgrade, Serbia, e-mail: info@vukmircetic.rs, ORCID ID: https://orcid. org/0000-0001-6675-5025

2 Svetlana Vukotić, Full Professor, Faculty of Applied Management, Economics and Finance, Jevrejska 24, Belgrade, Serbia, e-mail: svetlana.vukotic@mef.edu.rs, ORCID ID: https:// orcid.org/0000-0002-5179-7537

3 Drago Cvijanović, Full Professor, Faculty of Hotel Management and Tourism, University of Kragujevac, Vojvodjanska bb, 36210 Vrnjacka Banja, Serbia; e-Mail: drago.cvijanovic@ kg.ac.rs ORCID ID: https://orcid.org/0000-0002-4037-327X

http://ea.bg.ac.rs 
more demanding. In the last decades of the last century, tourism market gained a larger proportion and became more important. Tourism is a dynamic category that is continuously developing in the World (Cvijanović, et al., 2018) and consist of all phenomenon and relationship created from the interaction of tourists, suppliers and travel merchant, governments and communities in the process of tourists attraction and welcoming (Hadaiani et al., 2012).

Tourism stakeholders have to identify different approaches and tools to successfully present a tourist destination (Cvijanović et al., 2019). They develop effective models for the tourist markets to stay competitive and forming or joining a tourism cluster is one of the effective approaches. Clusters are not only a relatively new approach to business thinking, but they are also an inspirational theme in academic circles. Modern organizations are trans-organizational systems because do not represent a traditional exchange of the final product. They exchange information and knowledge, including reciprocal functions and obligations with partner firms. There are numerous forms of partnerships in tourism. Tourism is considered as fragmented industry and according to statements in the academic circles, the cluster approach is convenient for sectors or activities with fragmented structure. Hill and Jones (2004) point out that characteristics of fragmented industries are isolated markets with low entry barriers, low opportunities for large scale economies, overcoming focus strategy, such as consumer groups or regions. Competing in fragmented industries requires strategic consolidation through various forms of linking, horizontal merging, franchising, networks on Internet and cluster association. Bakić (2009) highlighted that the wideness of cooperation implies the need to establish regional cooperation in tourism and make integrated touristic products. This exceeds national barriers and networking of interests based on creating additional benefits for tourists.

Aim of research in this paper is to point out interests for forming clusters, and particularly to emphasize contributions and benefits of clustering in tourism. This paper has been divided into three parts. Authors began by addressing the need for adjusting to the new challenges on the tourist market caused by globalization and modern living. Next part of the paper refers to joining into clusters and cluster characteristics and concept of clustering to improve business. In the end part, the authors examined the analysis of different cluster models and proposed the most suitable tourism cluster model for Serbia. A context of cluster study is mostly referred to the cluster members. The paper could be useful to interested managers in tourism, creators of economic politics, decision-makers, and the general public.

\section{About clusters and clusterism}

Great popularization of clusters that have wide application in the developed business world is still actual. Even though it is nearly three decades since Porter (1990) made the term "cluster" popular and then encouraged by Krugman (1991), their importance is still present. Porter made the term "cluster" popular in theoretical circles, but it should be mentioned that it was even before (Marshall, Guillebaud, 1961). Porter (1998, p. 
78) has determined clusters as geographic concentrations of interconnected companies and institutions in a particular field, linked by commonalities and complementarities.

The activities of cluster members must be associated with cluster goal. Porter (1998) observe cluster influence on competition in three broad ways: (1) increasing the productivity of cluster members; (2) future productivity growth by driving the direction and pace of innovation; (3) stimulating the formation of new businesses that leads to expanding and strengthening of the cluster itself. Cluster members simultaneously cooperate and compete. Some authors (Martin, Sunley, 2003) consider that in the last few decades clusters have become a brand and they call it "Porter brand". Authors (Marshall, 1920; Porter, 1990; Krugman, 1991; Ellison, Glaeser, 1997) agree that the agglomeration of related economic activity is a central feature of economic geography. Porter (2007) determined clusters as geographic concentrations of firms, suppliers, support services, specialized infrastructure, producers of related products, and specialized institutions that arise in particular fields in particular areas. Clusters are geographic concentrations of related industries and associated institutions (Delgado et al., 2014). There are different theoretical approaches to clustering. Some emphasize its structure and characteristics, other economy impact and the need for clustering.

Organizations joined in clusters have better interactions and exchange of information, knowledge, and experiences which produce synergic effects. Linking in network structures, as well as horizontal and vertical merging, cluster members relativize their deficiencies and potentiate advantages thereby achieving the necessary competitiveness in the market (Vukotić et al., 2013). Initiatives for cluster development are an important direction in the economic politics, market opening and reducing the business expenses (Mauroner, 2015).

Holub-Iwan (2012) in his research found that cluster structures can be very diverse and it depends on the economic potential of the cluster members. Certain authors (Zheliazkov et al.., 2015) emphasize that, since 2000, researchers examined the characteristics of clusters, the ways of identifying them and their influence on the market environment. Nordin (2003) concurrently observe clusters as a group of companies that are forming alliances and cooperating and as competitors in certain areas. Rosenfeld (1998, p. 4) determined clusters as a geographically bounded concentration of interdependent businesses with active channels for business transactions, dialogue, and communications, and that collectively shares common opportunities and threats.

Vučković (2016) recognized clusters as an instrument for strengthening productivity and innovation in small and medium-sized businesses in the national economy. Feser (1998) emphasized that economic clusters are related and supporting institutions that are more competitive by their relationships and not just related and supporting industries and institutions. Clusters can be also considered as a complicated and sophisticated form of association of producers and private sector, scientific and educational institutions and the public sector (Parausić, \& Domazet, 2018).

Roelandt and den Hertog (1999) characterized clusters as networks of producers of strongly interdependent enterprises that are linked in a production chain that add more 
value. Cluster members are competing and collaborating simultaneously and because of that, clusters have a better chance to be more competitive on a global basis (Christensen et al., 2002). While working together, they are developing new services and products, which is crucial if cluster members plan to stay globally competitive.

There are many benefits of clustering, it leads to productivity growth, increased competitiveness, innovation boost, and local growth and regional development (Michael, 2003, 2004) According to the definition proposed by Bianci (2005), clusters are resulted by itself. Clusters contribute to internationalization, better technology use, the introduction of quality standards, having more qualified employees and mobility of investment. The main goal of clustering is increasing the competitiveness of cluster members and the cluster itself. Small and medium-sized enterprises join together to become a more significant partner to large businesses and more competitive in the global market. Some authors (Parausić, Domazet, 2018) point out that there are four important keys for growth and prosperity of the national economies: (1) Specialized knowledge; (2) Innovations; (3) Technology; and (4) Science. They observe clusters as an engine starting device of economic growth and investments. In their words, clusters represent a strong catalyst for innovation processes.

A very important benefit of clustering is knowledge transfer (Argote, Ingram, 2000). They consider knowledge transfer as the process through which one member of a cluster learns from the experience of another member. Transfer knowledge can be both oneway and multi-way process because even the smallest or the least experienced cluster member could possess some knowledge that is important to other cluster members but they are unfamiliar to it. Clusters became more popular and its usage spreads to different areas.

Clusters are very important for agriculture (Paraušić et al., 2013), sport (Gerke et al., 2018), tourism (Nordin, 2003; Fundeanu, 2015) and the development of modern technologies led to forming of E-clusters (Davidović, 2014). Paraušić and Domazet (2018) point out that countries with highly developed clusters simultaneously have high national innovation potential and inversely. These authors made a statement that developing clusters is a key factor of competitiveness and sustainable development of each economy. Anderson et al.. (1994) underlined that the principle of work is simple: build an effective network of relationships with major stakeholders and profit will not be missed (Kotler, Keller, 2006). Some of the benefits of clustering are shown in Figure 1.

For authors of this paper, clusters consist of more different stakeholders, including representatives of the public, private sector and non-governmental sector, individuals and other interested parties. All stakeholders are operating inside a cluster domain or supporting industry. 
Figure 1. Benefits of cluster members

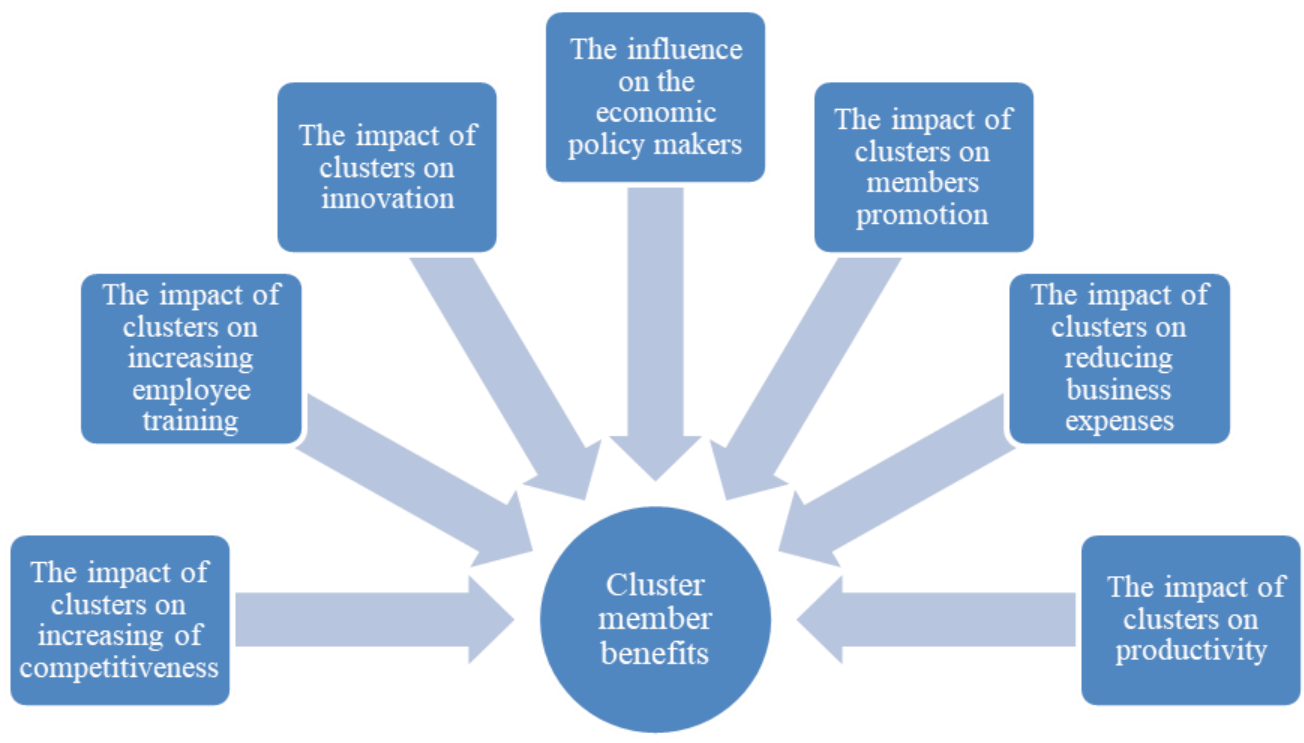

Source: Authors

The goal of the clustering formation is to improve business, extend collaboration with large enterprises and increase competitiveness locally and globally. While working to achieve the aim of clustering, cluster members carry out their regular activities, cooperate with each other and with partners, but also work on mutual knowledge sharing. Also, implementing effective leadership is extremely important to optimize the business process. Implementing effective leadership implies benefits for cluster members and they will operate effectively.

\section{About tourism clusters}

Tourism consists of various activities that lead to local development, increasing employees, creating new jobs and stimulating investments. All mentioned creates possibilities for establishing new organizations, such as small and medium-sized enterprises (da Cunha, da Cunha 2005, 48). Hotel business, transportation, souvenirs, and other products for tourists are also an important segment of the sphere of tourism (Sahakyan, Suvaryan, 2018).

Importance of tourism is reflected in its connection to other industries, such as transportation, culture, health industry, politics, etc (Cvijanović et al., 2016). These industries can be observed as supporting industries to tourism.

Modern tourism is dominated by requests for tailored experiences and that gives small and medium-sized enterprises a great opportunity to play a key role in providing adequate products and services to tourists. They are responding to their most specific 
interests and needs (Novelli et al., 2006) and some authors (Erkkila, 2004, p. 23) state that they constitute the lifeblood of the travel and tourism industry worldwide.

Tourism is generally considered in scientific literature as an industry that has a significant effect on the economic, social and functional structure of rural areas and as an essential factor in the revitalization and diversification of rural economy (Ristic et al., 2016). Michael $(2003,2004)$ analyzed the structure and the scale of clusters, especially when applied to the tourism context.

Tourism has frequently been launched as an alternative which potentially can contribute to a more positive development that attracts visitors, in-migrants, and investment, thus creating new employment and income opportunities in rural areas (Cawley, 2011; Halseth et al., 2010; Asa et al., 2016).

Role and impact of tourism in local growth and regional development have been tried to be explained through using networking, clustering and agglomeration theories. Knoke and Kuklinski (1983, p. 12) describe networks as a specific type of relation linking a set of persons, objects or events.

Kachniewska (2013) defined tourism clusters as an active network of tourism products manufacturers, supporting enterprisers of other industries, tourism organizations, local authorities and the local governments, facilities of business environment, educational and expert institutions, working together under a particular of a tourist product, and at the same time competing with each other in terms of the quality, innovation, and uniqueness of the offered services. Lately, more researchers use the cluster concept regarding tourism to promote competitiveness and innovation (Nordin, 2003; Fundeanu, 2015).

In a typical tourism cluster, the experience of tourist is affected not only by the attraction of the primary attractions, such as beaches or historical locality but also on the quality and effectiveness of the complementary businesses: hotels, restaurants, trade distributors and transport facilities. Lazzaretti and Kapone (2004) point out that cluster members are interdependent, so the good performance of one cluster member can enhance the success of the other. Tourism clusters are the result of complementary business organizations that may not necessarily be part of the same sector, but they benefit from network membership and linkage dynamics (Novelli et al., 2006). Inkpen and Tsang (2005) stated that cluster members are provided with access to knowledge, resources, markets, or technologies. This network can operate as a strategic alliance if the cluster members enter into a voluntary arrangement of exchanging, sharing or codeveloping products or services (Gulati, 1998).

Skowronek (2015) observe tourism clusters are as group consisted of different organizations, suppliers and service providers or businesses operating in the tourism sector or institutions connected to them, all set in the same geographical area. All cluster members at the same time compete and cooperate with each other (Beni, 2003). Staszewska (2009) highlighted three important parts as a driving force of the cluster: (1) Private sector; (2) Public sector; and (3) R\&D sector. 
Accordingly to the observation of clusters expressed in this paper, for authors of this paper, defining tourism clusters should be approached in the following manner: Tourism clusters are formal or informal networks which are consisted of different stakeholders, such as representatives of the public, private sector and non-governmental sector, individuals and other interested parties. All cluster members are operating within the domain of tourism or supporting industry. The aim of the tourism cluster is creating benefits of all cluster members and their direct and indirect partners in the process. Creating tourism clusters can make a great impact, as presented in Figure 2. Clustering leads to the improvement of tourist destination, and for the members of tourism clusters, it implies business process improvement, local and global competitiveness enhancement and individual development of cluster members, because of the experience and knowledge sharing. There are also indirect benefits for the local population because of the improvement of tourism in their geographical area.

Figure 2. Impact of tourism cluster members

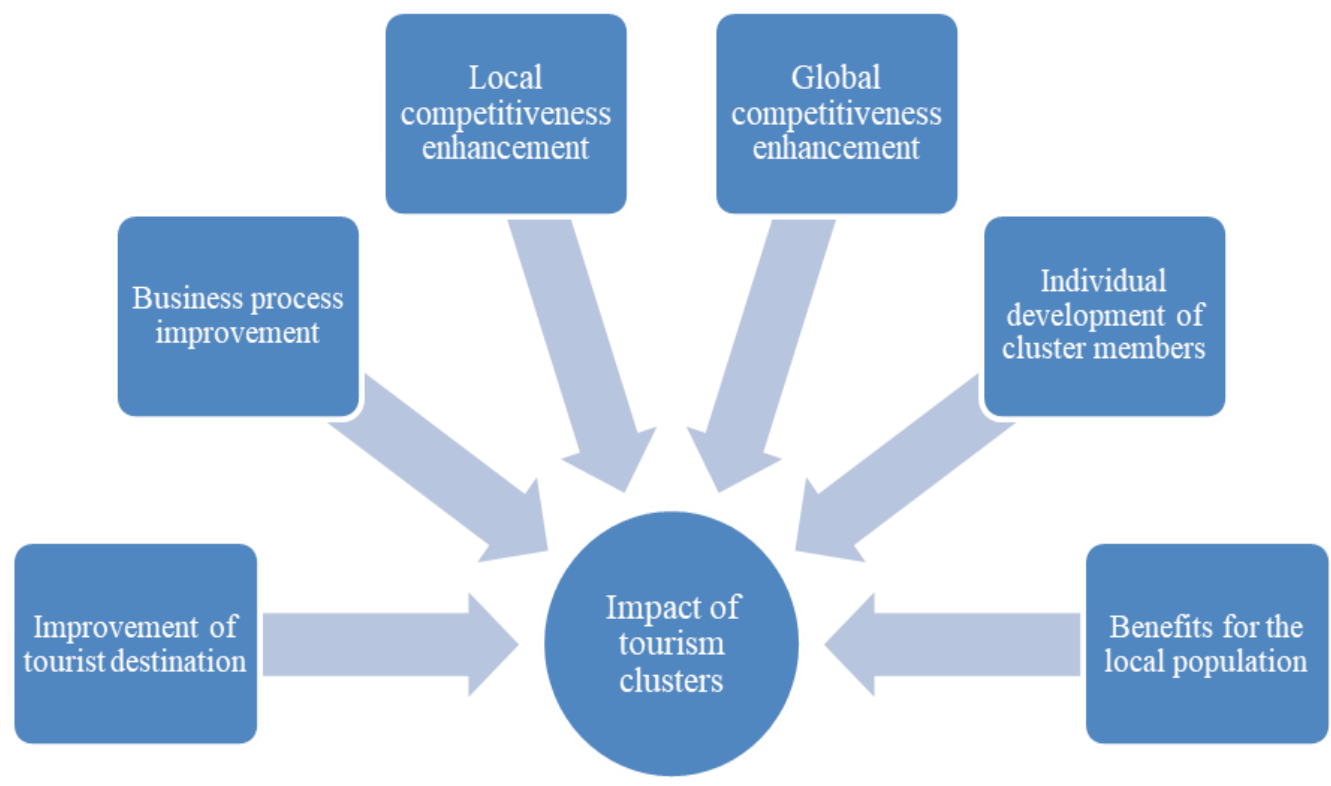

Source: Authors

\section{Comparative analysis of tourism clusters models}

Authors of this paper conducted a comparative analysis of tourism clusters in Europe to bring elaborate the role and the potential of tourism clusters and propose the most suitable tourism cluster model for Serbia. In the last two decades, many authors proposed their models of the tourism cluster. Some authors (Ritchie, Crouch, 2000; Kim, Wicks, 2010) developed their models of a tourism cluster based on the characteristics of the Porter diamond model. The peculiarity of the tourism cluster model proposed by 
Ritchie and Crouch (2000) is a transition from the traditional approach which is based on the attractiveness of tourist destination to the competitiveness of the destination. They identify four main components which determine the competitiveness of tourist destination: (1) Determining factors (location, safety, cost); (2) Destination management (administration, marketing, management, information services); (3) Basic resources and attractions (geographic location, culture, history, activities, special events); and (4) Supporting factors and resources (infrastructure, accessibility, resources, support).

The model that is developed by Kim and Wicks (2010) underlined four factors of the tourism cluster: (1) Key resources and attractions; (2) Management of the tourist destination; (3) Additional conditions; and (4) Demand conditions.

Da Cunha and da Cunha (2005) offered a model of the tourism cluster that highlights creating sustainable development based on cultural, institutional, social and environmental sustainability. It represents the levels of tourism cluster competitiveness: (1) Meta level; (2) Macro level; (3) Meso level; and (4) Micro level.

Ferreira and Estevão (2009) introduced the model of the tourism cluster in which the effectiveness of the tourist destination depends on the level of destination management, information services, promotional activities, hospitality and staff attitude. They underlined tour product, tourist destination and tourism cluster as three main components of the tourism cluster.

If a tourism cluster model is observed in a sense of a cluster broker, we are talking about the Danish model. This model recognized local governments, regional development agencies and chambers of commerce as cluster brokers, because of their experience regarding strategy management and finding the ways for improvement (investors, grants, marketing activities). This experience was also used in Poland. Tourism clusters are coordinated by tourism organizations, which also provide consulting activities, audit and promotion. Fundeanu (2015) analyzed in his paper using the same cluster model in the South-Western region of Oltenia in Romania. This cluster is called "Oltenia Tourism Competitiveness Pole-Innovation and Tradition in Tourism" and it represents a good example of cooperation between the public and private sectors, including chambers of commerce, schools, relevant associations and travel companies.

Novelli et al. (2006) researched recognition of cluster development in the United Kingdom as a key factor in the promotion of economic innovation and the success of small and medium-sized enterprises. In their words, clusters are important for the creation of conditions that encourage the development and progress of the business.

Capone (2016) shared his findings on analyzing tourism clusters in Western Europe. According to his research, there are approximately thirteen clusters that include one thousand of more firms and they are located in capital cities or popular tourist destination, such as Paris, Madrid, London, Barcelona, etc. In Europe, 392 clusters include more than one hundred firms and 471 consists of fifty to one hundred enterprises. Some authors (Babalola et al., 2011) indicate that in the tourism industry in Italy small and 
medium-sized enterprises predominate and that only about $3 \%$ of businesses consist of one thousand or more employees. The cooperation of local authorities and business in Italy are mostly underdeveloped. Although tourism clusters are still emerging, Italy is one of the leaders of international tourism.

"Innovative policy of Zhilina" is a project that is a part of the Regional Innovation Strategy of the Zilina region, started in 2005 and coordinated by the administration of the Zilina region on the North-West of Slovakia and the local university and other interested organizations. Project "Clusters and partnership" is also part of this strategy (Szekely, 2010).

Conducted analysis showed that a unique model of a tourism cluster must be developed for each geographic area. Tourism clusters can be formed at five different levels, micro, regional, pan-regional, national and international. Tourism clusters at the micro level include cluster members from one relatively small, homogeneous environment. Regional tourism clusters are formed on the territory of one municipality, city or region. These clusters consist of members that are from heterogeneous areas with different geographical or other features. Pan-regional tourism clusters are formed because two or more regions share some mutual characteristic. For example, it can be a larger area that consists of several regions, but there are one or more attributes that they share. National tourism clusters are self-explanatory. They represent tourism clusters formed on the ground on one country and if cluster members are from two or more countries, we are considering pan-national tourism clusters.

Conducted analysis showed that tourism clusters can seem similar, but every cluster has its specificities which make it unique. Tourism policymakers should have that in mind while working on tourism cluster forming.

\section{Tourism clusters in Serbia}

There are numerous cluster initiatives in Serbia, but it is hard to determine the exact number because there is not a unique database or cluster register (Vukotić et al., 2014). Additionally, not all clusters are formally registered. There are many clusters legally registered in Serbia, but they are underdeveloped and not operative in practice, or they are starting developing with untrusting cooperation between participants (Mijačić, 2011; Paraušić et al., 2013; Paraušić, Cvijanović, 2014). Clusters are a way of improving innovation potential in the Serbian economy (Paraušić, Domazet, 2018). Pandurević (2012) concluded that the results of policy implementation based on clusters do not correspond with the expectations and potential for cluster-related economic development. In the research of Aničić et al. (2013), it cen be see that development of clusters in Serbia began in 2004 through the mobilization of interested parties and improving capacities on the national level, firstly ministry responsible for tourism. Strengthening of business infrastructure is embedded in many strategic documents of the Government of the Republic of Serbia and acts of local self-governments. The cluster development process is assisted also by international organizations and 
programs. Their analysis also showed that the development level of clusters in Serbia is still unnoticed.

In 2019, the National Assembly of the Republic of Serbia passed a new Law on Tourism and content related to tourism clusters stayed unchanged compared to Law on Tourism from 2009. Forming of tourism clusters are elaborated in the Strategy for Tourism Development from 2006 to 2015. According to that Strategy, there are four tourism clusters: (1) Vojvodina; (2) Belgrade; (3) Western Serbia with Kosovo and Metohija; and (4) Eastern Serbia. These four clusters were only formally proposed and they never implemented completely. New Strategy for Tourism Development adopted in 2016 does not have a division into four tourism clusters and event do not mention the word "cluster" at all. In practice, despite having proposed tourism clusters from 2006 to 2015, many independent tourism clusters are formed, as shown in Table 1.

Table 1. List of tourism clusters in Serbia

\begin{tabular}{|c|c|c|}
\hline $\mathrm{Nr}$ & Tourism cluster & $\begin{array}{c}\text { Year of } \\
\text { establishment }\end{array}$ \\
\hline 1. & Fond health tourism cluster of Vojvodina, Kanjiža & 2007 \\
\hline 2. & Fond tourism cluster of micro region Subotica - Palić & $2007^{1}$ \\
\hline 3. & Danube tourism cluster "ISTAR 21", Novi Sad & 2008 \\
\hline 4. & Association for development of business and manifestation tourism & 2008 \\
\hline 5. & Tourism cluster of Kraljevo "Kraljevski odmor" & 2008 \\
\hline 6. & Organization for hotel industry and gastronomy development HGS & 2008 \\
\hline 7. & Cluster of medicine tourism & 2009 \\
\hline 8. & Cluster of tourism micro region of Sremska Mitrovica, Sveti Dimitrije & 2009 \\
\hline 9. & Fond tourism cluster Srem & 2009 \\
\hline 10. & Tourism cluster of South-East Serbia, Stara planina - Knjaževac & 2010 \\
\hline 11. & Cluster of medicine and health tourism - Vrnjačka Banja & 2011 \\
\hline 12. & Tourism initiative Tronožac, TTI & 2011 \\
\hline 13. & Cluster of rural tourism, Čarolija istoka & 2011 \\
\hline 14. & Tourism cluster of micro region Apatin & 2011 \\
\hline 15. & Cluster for development of business manifestation tourism & 2012 \\
\hline 16. & Banat tourism cluster & 2012 \\
\hline 17. & Cluster of health, wellness and spa tourism & 2012 \\
\hline 18. & Cluster for developing of rural tourism in Vojvodina & 2012 \\
\hline 19. & Tourism business cluster of Savski venac "Venac dobre usluge" & 2012 \\
\hline 20. & Tourism cluster of Radan area & 2012 \\
\hline 21. & Tourism cluster Avala & 2013 \\
\hline 22. & Cluster of travel agencies and hoteliers of Sandžak & 2013 \\
\hline 23. & Cluster educational tourism of Serbia & 2013 \\
\hline 24. & Tourism cluster "Srce Šumadije" - Aranđelovac & 2014 \\
\hline
\end{tabular}

Source: Authors

Examining data from Table 1, it can be seen that most tourism clusters are founded in 2012, six of them, and then 2008 and 2011 with four formed tourism clusters. The regional layout of the tourism clusters in Serbia is shown in the following map in Figure 3. 
Figure 3. Tourism clusters in Serbia

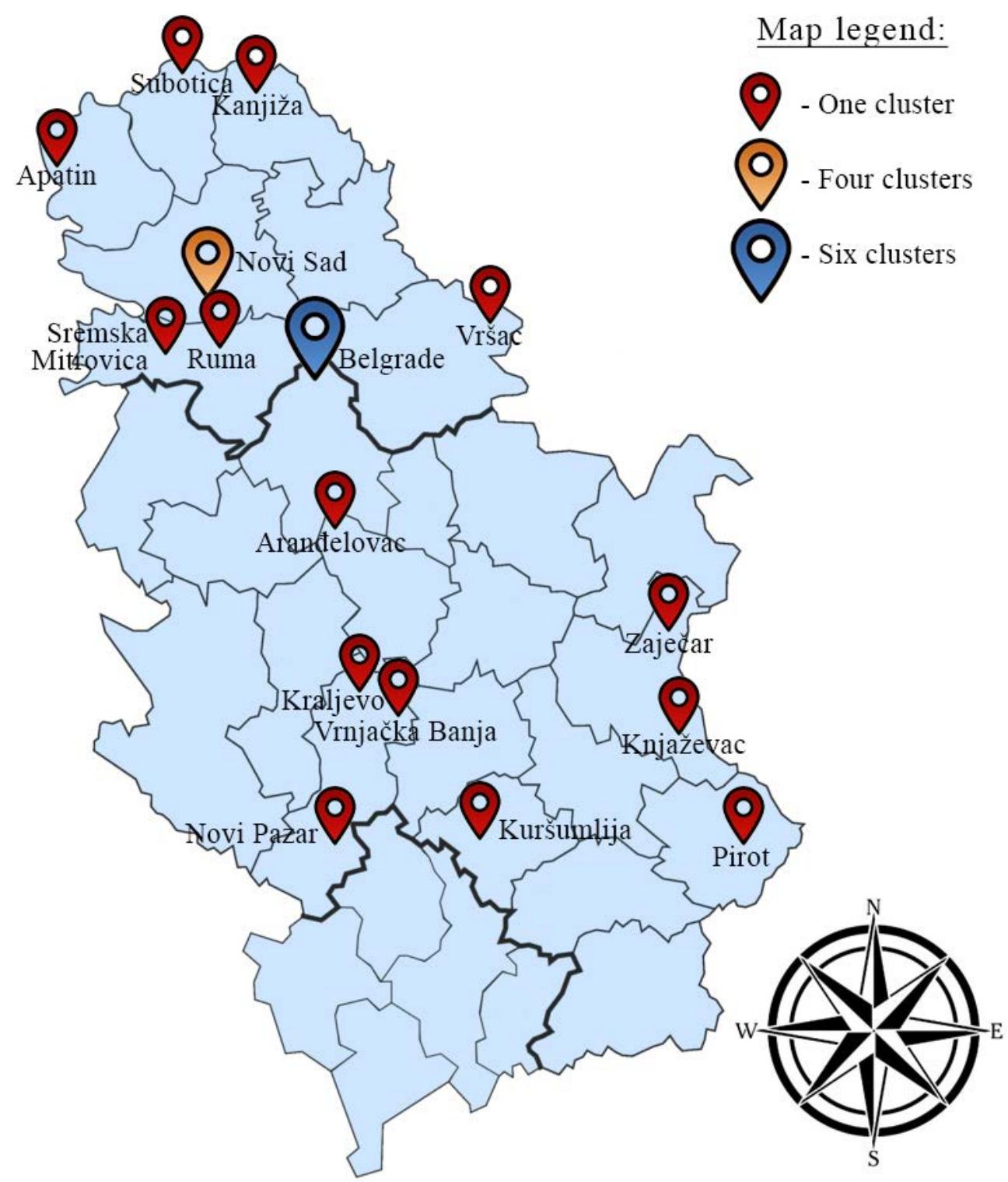

Source: Authors

Authors analyzed twenty-four tourism clusters that can be found. Examining cluster locations in Serbia on Figure 1, authors realized that the most clusters are formed in the Capital city of The Republic of Serbia, Belgrade, six of them. There are four tourism clusters in Novi Sad and other clusters are located in other cities or districts. District with the most clusters is Raška district with three formed tourism clusters (Kraljevo, Vrnjačka Banja and Novi Pazar). 
Two clusters are formed in Srem district (Ruma and Sremska Mitrovica) and Zaječar district (Zaječar and Knjaževac). Following micro-regions, municipalities or cities are the only tourism cluster representatives for their districts and have one formed tourism cluster: Subotica-Palić micro-region, Apatin, Kanjiža, Vršac, Aranđelovac, Pirot, and Kuršumlija.

Many municipalities, cities, and districts in Serbia have great tourism potential, but they do not have formed tourism clusters, as shown in Figure 1. Decision-makers should further examine existing cluster locations and propose forming of new tourism clusters in the areas with tourism potential, such as rural tourism, where tourism clusters do not exist.

Concept authors proposed was the guidance for proposal tourism cluster model for Serbia. The ideal model for Serbia would be a tourism cluster at the micro level because large clusters proposed in Strategy for Tourism Development from 2006 were not implemented as planned. Tourism policymakers have to include all stakeholders in the clustering process, representatives of the public, private sector and non-governmental sector, individuals and other interested parties operating in tourism or supporting industry.

\section{Conclusion}

The objective of this paper was to examine the theoretical approach to clustering, with special reference to tourism clusters. Results of this paper research have theoretical and practical value.

Tourists are becoming more demanding due to the variety of tourist destination. To respond to their needs and requests, organizations working in tourism sphere have to achieve an optimal level of their business process. Many organizations choose to form wide networks with other tourism stakeholders and create clusters.

Contribution of this paper to science is through understanding and advancing significant issues regarding the impact of business clusters on tourism. Authors identified different direct benefits for all cluster members and indirect impact on the local community. Conducted a comprehensive analysis of various tourism cluster models showed that a unique model must be developed for each region or country. Tourism policymakers should first examine the current situation and based on the environmental characteristics determine the well-defined cluster model which will be used in that region only. Cluster model proposed for one geographical area could be replicated in other locations with similar needs or characteristics, but this research recommended creating new models concerning the specificities of that location.

In practice, findings of this research could give tourism policymakers, decision-makers and researchers in the tourism sphere guidelines regarding business clusters. Forming tourism clusters as the widest functional-market and spatial units of Serbian tourism would lead to achieving the simplification of regional tourism brands and emphasize well-known geographical concepts, differentiated positioning of clusters in the market, improving the attractiveness, marketing, productivity, and destination management. Implementing a clustering strategy would benefit all stakeholders and make a greater impact. 


\section{Acknowledgements}

The paper is part of the research at the project III-46006"Sustainable agriculture and rural development in terms of the Republic of Serbia strategic goals realization within the Danube region", financed by the Ministry of Education, Science and Technological Development of the Republic of Serbia.

\section{Conflict of interests}

The authors declare no conflict of interest.

\section{References}

1. Anderson, J. C., Håkansson, H., \& Johanson, J. (1994). Dyadic Business Relationships Within a Business Network Context. Journal of Marketing, 58, 1-15.

2. Aničić, J., Vukotić, S., Zakić, N., Laketa, M., \& Laketa, L. (2013). Clusters as a Model of Economic Development of Serbia, UTMS Journal of Economics, 4 (3), 341-354.

3. Argote, L., \& Ingram, P. (2000). Knowledge transfer: A basis for competitive advantage in firms. Organizational Behaviour and Human Decision Processes, 82, $150-169$.

4. Asa, A., Lundmark, L., \& Pettersson, O. (2016): Public spending on rural tourism in Sweden, Fennia. Geographical Society of Finland, 194 (1), 18-31.

5. Babalola, A., Bennis, K., Caltigirone, M., Manjarrez, J. L., \& Tanizawa, A. (2011). Tourism Cluster in Italy, Microeconomic of Competitiveness.

6. Bakić, O. (2009). Prilagođavanja marketing menadžmenta u turističkim destinacijama u uslovima globalizacije i klasterizacije u turizmu, Marketing, 40 (4), str. 202-211. [in English: Bakić, O. (2009). Adaptations of marketing management in tourist destinations in conditions of globalization and clustering in tourism. Marketing, 40 (4), 202-211]

7. Beni, M. C. (2003). Globalização do turismo: megatendencias do setor e a realidadebrasileira. Aleph, São Paulo.

8. Bianchi, M., (2005). Cluster analysis or NewBuC? Some lessons from projects of SME creation in Transition Countries, M. Bianchi and L. Tampieri (eds) Life Long Leraning and Managerial Development in Transation Countries, Cesena: II Ponte Vecchio.

9. Capone F. (2016). Tourist Clusters, Destinations and Competitiveness: Theoretical issues and empirical evidence, edited by, Routledge Taylor and Francis Group, London, New York.

10. Cawley, M. (2011): Adding value locally through integrated rural tourism: lessons from Ireland, Proceedings from the conference - The next rural economies: constructing rural place in global economies, Wallingford, England, pp. 89-101. 
11. Christensen, P., McIntyre, N., \& Pikholz, L. (2002). Bridging community and economic development - A strategy for using industry clusters to link neighbourhoods to the regional economy.

12. Cvijanović, D., Aničić, J., \& Vukotić, S. (2018). Preduzetništvo mladih i žena u SrbijiTurizamkaoizazov. UniverzitetuKragujevcu,Fakultetzahotelijerstvoiturizamu Vrnjačkoj Banji. [in English: Cvijanović, D., Aničić, J., Vukotić, S. (2018). Entrepreneurship of young people and women in Serbia - Tourism as a challenge. University of Kragujevac, Faculty of Hotel Management and Tourism in Vrnjačka Banja.]

13. Cvijanović, D., Mihailović, B, \& Vukotić, S. (2016). Marketing i konstalting $u$ funkciji razvoja turizma Srbije. Beograd: Institut za ekonomiku poljoprivrede. [in English: Cvijanović, D., Mihailović, B, \& Vukotić, S. (2016). Marketing and consulting in function of tourism development in Serbia. Belgrade: Institute of Agricultural Economics.]

14. Cvijanović, D., Mirčetić, V., \& Vukotić, S. (2019). Razvoj i definisanje brenda turističke destinacije. Zbornik radova VIII međunarodnog simpozijuma o upravljanju prirodnim resursima ISNRM 2019 (str. 303-309). Zaječar, Srbija, 31. maj 2018: Megatrend Univerzitet Beograd, Fakultet za menadžment Zaječar. ISBN: 978-86-7747-606-9. [in English: Cvijanović, D., Mirčetić, V., \& Vukotić, S. (2019). Developing and Defining Tourism Destination Brand. In the Book of Proceedings of $9^{\text {th }}$ International Symposium on Natural Resources Management ISNRM 2019 (pp. 303-309). Zaječar, Serbia: Faculty of Management, Zaječar, Megatrend University, Belgrade.]

15. Da Cunha, S.K., \& da Cunha, J.C. (2005). Tourism cluster competitiveness and sustainability: proposal for a systemic model to measure the impact of tourism on local development. BAR - Brazilian Administration Review, 2(2), 47-62. DOI: 10.1590/S1807-76922005000200005

16. Davidović, M. (2014). Development of e-clusters, Information and Communication Technology. Electronics and Microelectronics (MIPRO), 37th International Convention on, Opatija, IEEE, 1563 - 1568.

17. Delgado, M., Porter, M., \& Stern, S. (2014). Defining Clusters of Related Industries. Journal of Economic Geography, 16 (1), 1-38.

18. Ellison, G., \& Glaeser, E. (1997). Geographic Concentration in U.S. Manufacturing Industries: A Dartboard Approach. Journal of Political Economy, 105, 889-927.

19. Erkkila, D. (2004). Introduction to Section 1: SMEs in regional development. In P. Keller, \& T. Bieger (Eds.), The future of small and medium sized enterprises in tourism, Vol. 46 (pp. 23-34). Petra Jordan: AIEST 54th Congress.

20. Ferreira, J., \& Estevão, C. (2009). Regional Competitiveness of Tourism Cluster: a Conceptual Model Proposal. MPRA Paper (14853), pp. 1-20.

21. Feser, E. J., (1998): Old and New Theories of Industry Clusters, in: Steiner, M. (ed.), Clusters and Regional Specialisation: On Geography, Technology and Networks, London: Pion, 18-40. 
22. Fundeanu, D. D. (2015). Innovative Regional Cluster, Model of Tourism Development. 2nd Global Conference on Business, Economics, Management and Tourism 23: 744-749. doi: 10.1016/S2212-5671(15)00501-8.

23. Gerke, A., Babiak, K., Dickson, G., \& Desbordes, M. (2018). Developmental processes and motivations for linkages in cross-sectoral sport clusters. Sport Management Review, 21(2), 133-146

24. Gulati, R. (1998). Alliances and networks. Strategic Management Journal, 19, 293-317.

25. Hadaiani, Z., Ahadnezhad, M., Kazemizad, S., \& Ghanbari, H. (2012). Strategic Planning for Tourism Development by SWOT Method (Case Study: Shiraz City). Geography and Environmental Planning Journal, $23^{\text {rd }}$ Year, vol. 27, No. 3, Autumn, 29-32.

26. Halseth, G., Markey, S., \& Bruce, D. (2010). The next rural economies: constructing rural place in global economies, CABI Publishing, Wallingford, England.

27. Hill, C., \& Jones, G. (2001). Strategic Management An Integrated Approach, 5th Edition. Houghton Mifflin Company.

28. Holub-Iwan, J. (ed.) (2012). Benchmarking klastrow w Polsce-edycja 2012. Raport $z$ badania. Warszawa: PARP [in English: Holub-Iwan, J. (ed.) (2012). Cluster Benchmarking in Poland - 2012 edition. Report from the survey. Warszawa: PARP]

29. Inkpen, A. C., \& Tsang, E. W. K. (2005). Social capital, networks, and knowledge transfer. Academy of Management Review, 30(1), 146-165.

30. Kachniewska, M. (2013). Towards the Definition of a Tourism Cluster. Journal of Entrepreneurship, Management and Innovation, 9(1), 33-56.

31. Kim, N., \& Wicks, B.E. (2010). Rethinking Tourism Cluster Development Models for Global Competitiveness. Paper read at 2010 ICHRIE Conference, 2010.07.2831, at San Juan, Puerto Rico, USA.

32. Knoke, D., \& Kuklinski, J. (1983). Network analysis. Los Angeles: Sage.

33. Kotler, P., \& Keller, K. L. (2006). Marketing menadžment, 12. izdanje (prevod). Beograd: Data status. [in English: Kotler, P., Keller, K.L. (2006). Marketing management, $12^{\text {th }}$ Issue (translation). Belgrade: Data status].

34. Krugman, P. (1991). Geography and Trade. MIT Press. Cambridge, MA.

35. Zakon o turizmu. (2009) Službeni glasnik Republike Srbije, 36/2009, 88/2010, 99/2011 - dr. zakon, 93/2012 i 84/2015. [in English: Law on Tourism. (2009). Official Gazette of the Republic of Serbia, 36/2009, 88/2010, 99/2011 - other law, 93/2012 and 84/2015].

36. Zakon o turizmu. (2019) Službeni glasnik Republike Srbije, 17/2019. [in English: Law on Tourism, Official Gazette of the Republic of Serbia, 17/2019] 
37. Lazzeretti, L., \& Capone, F. (2004). Identification and Analysis of Tourist Local Systems: An Application to Italy (1996-2001), in Proceedings: Networking in Tourist Local Systems, ATLAS, Annual Conference. Naples, Italy, pp. 25-41.

38. Marshall, A. (1920). Principles of Economics ( $8^{\text {th }}$ Edition). Macmillian: London.

39. Marshall, A., \& Guillebaud, C.W. (1961). Principles of Economics. 9th (variorum) ed., 2 vol. London - New York: Macmillan for the Royal Economic Society.

40. Martin, R., \& Sunley, P. (2003). Deconstructing Clusters: Chaotic Concept or Policy? Journal of Economic Geography, 3(1), 5-35. https://doi.org/10.1093/ jeg/3.1.5.

41. Mauroner, O. (2015). Innovativaion Clusters and Public Policy - The Case of Reserarch - Driven Cluster in Germany, American Journal of Industrial and Business Management, 5(12), 736-747. doi: 10.4236/ajibm.2015.512072

42. Michael, E. J. (2003). Tourism micro-clusters. Tourism Economics, 9(2), 133-145.

43. Michael, E. J. (2004). Tourism micro-clusters from principle to practice. Tourism State of the Art II - Conference proceedings, Scottish Hotel School, University of Strathclyde, Glasgow, June 2004, CD.

44. Mijačić, D. (2011). Analiza stanja poslovne infrastrukture u Republici Srbiji. Nacionalna agencija za regionalni razvoj. [in English: Mijačić, D. (2011). Analysis of business infrastructure in the Republic of Serbia. National Agency for Regional Development]

45. Nordin, S. (2003). Tourism clustering and innovation-Paths to economic growth and development. European tourism Research Institute, Mid-Sweden University.

46. Novelli, M., Schmitz, B., \& Spencer, T. (2006). Networks, clusters and innovation in tourism: A UK experience. Tourism Management 27. 1141-1152

47. Pandurević, N. (2012). Klasteri i regionalni ekonomski razvoj geografska koncentracija malih i srednjih preduzeća kao izvor konkurentske prednosti, Ekonomika, LVIII; IV-VI, broj 2, str. 159-169. [in English: Pandurević, N. (2012). Clusters and regional economic development, geographic concentration of SMEs as a resource of competitive advantage, Economics, LVIII; IV-VI, number 2, pp. 159-169]

48. Paraušić, V., \& Cvijanović, J. (2014). Konkurentnost agroprivrede Srbije - klasteri u funkciji održive regionalne konkurentnosti. Beograd: Institut za ekonomiku poljoprivrede. [in English: Paraušić, V., Cvijanović, J. (2014). Competitiveness of Serbian agro-economy - clusters in function of sustainable regional competitiveness. Belgrade: Institute of Agricultural Economics]

49. Paraušić, V., Cvijanović, J., \& Mihailović, B. (2013). Market analysis of clusters in Serbian agribusiness. Economics of Agriculture, 60(4), 713-728.

50. Parausić, V., \& Domazet, I. (2018). Cluster Development and Innovative Potential in Serbian Agriculture. Economics of Agriculture, 65(3), 1159-1170.

51. Porter, M. E. (1990). The Competitive Advantage of Nations. Free Press, New York. 
52. Porter, M. E. (1998). Clusters and the new economics of competition. Harvard Business Review, 76(6), 77-90.

53. Porter, M. E. (2007). Clusters and Economic Policy: Aligning Public Policy with the New Economics of Competition. Harvard Business School, Institute for Strategy and Competitiveness, ISC White Paper XI.

54. Ristić, L., Vujičić, M., \& Leković, M. (2016). Tourism as a factor of sustainable development of rural areas belonging to Rudnička Morava. Economics of Agriculture, 63(2), 665-680.

55. Ritchie, J. R. B., \& Crouch, G. I. (2000), The competitive destination, a sustainable perspective, Tourism Management, 21 (1), 1-7.

56. Roelandt, T., \& den Hertog, P. (1999). Cluster analysis and cluster-based policy making in OECD countries: an introduction to the theme, chapter 1 in OECD, Boosting innovation: the cluster approach. Paris: OECD, pp. 9-23.

57. Rosenfeld, S. (1998). Business clusters in America: Strategies and synergies, draft prepared for Organisation for Economic Cooperation and Development, Paris, France. In P. Christensen, N. McIntyre, \& L. Pikholz (Eds.). Bridging community and economic development - A strategy for using industry clusters to link neighbourhoods to the regional economy, 2002.

58. Sahakyan, M., \& Suvaryan, A. (2018). Conceptual Model of a Tourism Cluster in Armenia. Barometr Regionalny. Tom 16, number 3.

59. Skowronek, E. (2015). Klaster jako forma wspolpracy w turystyce. Europa Regionum, vol. 24, pp. 129-140. [in English: Skowronek, E. (2015). Cluster as a form of cooperation in tourism. Europa Regionum, vol. 24, pp. 129-140.].

60. Staszewska, J. (2009). Klaster perspektywą dla przedsiebiorcow na polskim rynku turystycznym. Warszawa: Centrum Doradztwa i Informacji Difin Sp. z o.o. [in English: Staszewska, J. (2009). The cluster is a perspective for entrepreneurs on the Polish tourist market. Warszawa: Centrum Doradztwa i Informacji Difin Sp. z o.o.]

61. Strategija razvoja turizma Republike Srbije za period od 2005. do 2016. godine. (2005). Vlada Republike Srbije. [in English: Strategy for Tourism Development of the Republic of Serbia for the period from 2005 to 2016. (2016). The Government of the Republic of Serbia.].

62. Strategija razvoja turizma Republike Srbije za period od 2016. do 2025. godine. (2016). Vlada Republike Srbije. [in English: Strategy for Tourism Development of the Republic of Serbia for the period from 2016 to 2025. (2016). The Government of the Republic of Serbia.].

63. Szekely, V. (2010). Tourism Clusters as a Tool for the Improvement of Rural Competitiveness: First Experience from Slovakia, In: A. Fieldsend (ed.), Rural Areas and Development, 7-Linking Competitiveness with Equity and Sustainability: New Ideas for Socio-Economic Development of Rural Areas, Warsaw (European Rural Development Network), 109-120. 
64. Vučković, B. (2016). Causes of Different Profitability of Agricultural Sector. Economics of Agriculture, 1/2016, 123-141.

65. Vukotić, S., Aničić, J., \& Laketa, M. (2013). Clusters as a Part of Improvement Function of Serbian Economy Real Sector Competitiveness, Amfiteatru Economic, Vol. XV, No. 33, February, pp. 224-245.

66. Vukotić, S., Cvijanovič, D., \& Aničić, J. (2014). Mala i srednja preduzeća - Ključ uspeha u klasterskom povezivanju. Beograd: Institut za ekonomiku poljoprivrede. [in English: Vukotić, S., Cvijanovič, D., Aničić, J. (2014). Small and Medium-sized Enterprises - The Key for the Success in Clustering Business. Belgrade: Institute of Agricultural Economics].

67. Zheliazkov, G., Zaimova, D., Genchev, E., \& Toneva, K. (2015). Cluster development in rural areas. Economics of Agriculture, 62(1), 73-93. 